\title{
SISTEM INFORMASI PERSEDIAAN DAN PENJUALAN OBAT BATIK PADA TOKO WARNA MULIA BERBASIS WEB
}

\author{
${ }^{1}$ Aslam Fatkhudin \\ Jurusan Manajemen Informatika \\ Politeknik Muhammadiyah Pekalongan \\ Jl. Pahlawan No.10 Gejlig - Kec. Kajen, Kab. Pekalongan
}

\begin{abstract}
Warna Muliashop is one of the businesses engaged in the sale of batik colors. During this batik color sales in Warna Mulia shop done in two ways, namely direct sales through the store served by the cashier and to form a marketing team to market to batik entrepreneur. In the marketing process, sometimes the information conveyed to consumers are less accurate, leading to problems regarding the delivery of information to customers batik colors supply which impact on the slow progress of the business cycle store sales. In addition the system is running in the store Warna Mulia today is the process of recording sales transactions and inventory data is still written in the memorandum and books. Making the inventory system and web-based sales at stores Color Majesty is a step to facilitate the delivery of information and business management in the field of colors supply and sale of batik. The system is built using the PHP programming language and MySQL database and the editor using Macromedia Dreamwever. Results of the study is the process of selling goods using the online application that automatically connects directly to the store database. This app also contains reporting process sales transactions, inventory, income and expenses.
\end{abstract}

Keywords: Batik, Information Systems,Inventory, Sales.

\begin{abstract}
Abstraksi
Toko Warna Mulia merupakan salah satu usaha yang bergerak di bidang penjualan obat batik. Selama ini penjualan obat batik pada Toko Warna Mulia dilakukan melalui dua cara, yaitu penjualan langsung melalui toko yang dilayani oleh kasir dan dengan membentuk tim marketing untuk memasarkan ke pengusaha batik.Dalam proses pemasarannya, terkadang informasi yang disampaikan ke konsumen kurang akurat, sehingga menimbulkan masalah mengenai penyampaian informasi persediaan obat batik kepada pelanggan yang berimbas kepada lambatnya kemajuan roda bisnis penjualan toko tersebut. Selain itu sistem yang sedang berjalan di toko Warna Mulia saat ini adalah proses pencatatan data transaksi penjualan dan persediaan masih ditulis dalam nota dan buku. Pembuatan sistem persediaan danpenjualan berbasis web pada toko Warna Mulia merupakan langkah untuk mempermudah penyampaian informasi dan pengelolaan usaha dalam bidang persediaan dan penjualan obat batik. Sistem ini dibuat menggunakan bahasa pemprograman Php dan database MySQL dan editornya menggunakan Macromedia Dreamwever. Hasil dari penelitian adalah Proses penjualan barang menggunakan aplikasi online yang secara otomatis terhubung langsung ke database toko.Aplikasi ini juga berisi laporan proses transaksi penjualan, persediaan barang, pendapatan dan pengeluaran.
\end{abstract}

Kata kunci : Batik, Penjualan,Persediaan, Sistem Informasi. 


\section{Pendahuluan}

Batik merupakan salah satu aset kebudayaan nasional yang telah diakui oleh UNESCO pada tahun 2009 sebagai warisan asli budaya Indonesia (Ulung, 2011). Dengan diakuinya batik sebagai warisan budaya asli Indonesia, semakin menumbuhkan banyak home industri yang bergerak dibidang produksi batik. Produksi batik esensinya adalah menghias permukaan kain dengan corak atau motif dalam berbagai warna, sehingga membentuk suatu lukisan yang memiliki nilai jual. Dalam perkembangannya suatu karya batik yang dianggap memiliki nilai jual tinggi dapat diketahui berdasarkan kualitas motif corak pewarnaan.Semakinhalus dan rapi corak pewarnaannyaserta dapat bertahan lama (tidak luntur), maka batik tersebut memiliki nilai jual yang tinggi(Elliott, 2004).

Warna batik yang baik diperlukan bahan kimia pewarna batik (obat batik) yang berkualitas baik pula. Maka informasi mengenai obat batik yang berkualitas sangat dibutuhkan oleh masyarakat khususnya para pengrajin batik. sehingga sangat memerlukan adanya sistem informasi pengolahan data untuk mempermudah dan memperlancar kinerjanya.Dengan informasi tersebut para pengusaha dapat memprediksi keadaan ataupun kebutuhan masa depan, sehingga mereka dapat mengambil keputusan dan melakukan tindakan yang terbaik untuk kemajuan usahanya. Adanya kepentingan tersebut, maka informasi yang tersedia haruslah informasi yang berkualitas yakni informasi yang akurat, tepat waktu dan relevan (Astuti, 2013).

Kebutuhan terhadap informasi yang berkualitas tersebut dirasakan pula oleh Toko Warna Mulia yang merupakan salah satu usaha bergerak di bidang penjualan obat batik. Berdasarkan hasil wawancara terhadap pemilik toko Warna Mulia, untuk meningkatkan omzet pendapatan, penjualan pada Toko Warna Mulia dilakukan melalui dua cara,yaitu penjualan langsung di tokonya yang dilayani oleh kasir dan dengan membentuk tim marketing untuk memasarkan ke pengusaha batik. Dalam proses pemasarannya, terkadang informasi yang disampaikan ke konsumen kurang akurat, sehingga menimbulkan masalah mengenai penyampaian informasi persediaan obat batik kepada pelanggan yang berimbas kepada lambatnya kemajuan roda bisnis penjualan toko tersebut. Selain itu sistem yang sedang berjalan di toko Warna Muliasaat ini adalah proses pencatatan data transaksi penjualan dan persediaan masih ditulis dalam nota dan buku. Dengan sistem yang berjalan saat ini, yaitu hanya berupa pencatatan dan penyimpanan data transaksi dalam bentuk lembaran kertas atau catatan di buku saja yang disimpan dalam sebuah rak, menyebabkan karyawan kesulitan dalam pencarian data-data transaksi, terutama pada saat data atau dokumen transaksi semakin banyak,sehingga proses pembuatan laporan membutuhkan waktu lama, karena harus membuat rekapitulasi dari dokumen-dokumen transaksi(Mauluddin, 2011).

Untuk mengatasi permasalahan tersebut penulis terdorong untuk merancang sebuah sistem yang dapat mempermudah toko Warna Mulia dalam memberikan informasi persediaan dan penjualan obat batik secara efektif dan akurat yang dapat diakses dimanapun dan kapanpun secara online.

Berdasarkan latar belakang masalah yang telah diuraikan diatas maka dapat diidentifikasi masalahnya, yaitu sebagai berikut:

1. Proses pencatatan data transaksi penjualan dan persediaan masih ditulis dalam bentuk lembaran kertas nota dan buku penjualan maupun buku persediaan, sehingga laporan penjualan dan persediaan obat batik belum efisien.

2. Proses penyimpanan pendataan transaksi masih disimpan dalam sebuah rak.

3. Belum adanya sistem informasi yang akurat mengenai stok barang. 
Beberapa penelitian mengenai Sistem Informasi Persediaan dan Penjualan memang pernah dilakukan, diantaranya penelitian dengan judul Sistem Informasi Penjualan Barang pada Toko Sumber Urip Berbasis Web. Penelitian inidilatarbelkangi oleh proses transaksi penjualan sembako yang masih ditulis pada buku penjualan dan untuk mengetahui stok barang yang ada digudang juga harus mengecek satu persatu. Penelitianini bertujuan untukmembuatsistem informasi penjualan barang agar dapat mempermudah proses pelaporan stock barang (inventori),dengan demikian sistem dapat meningkatkan kinerja toko sumber urip(Rini, 2010).

Penelitian lainnya mengenai Sistem Informasi Persediaan dan Penjualan Barang Berbasis Web pada Toko Batik Terang Bulan. Penelitiannya dilatarbelkangi oleh kegiatan penjualan batik pada Toko Batik Terang BulanYogyakarta yang masih dilakukan secara manual. Salah satu informasi yang dibutuhkan pada toko batik Terang Bulan mengenai persediaan barang. Hal ini membutuhkan ketelitian supaya dalam setiap pelaporan tidak terjadi kesalahan yang lebih besar. Hal tersebut dapat dihindarkan dengan menggunakan suatu sistem aplikasi berbasis web agar dapat menyajikan informasi secara tepat. Sistem ini juga bertujuan mampu menyajikan informasi yangtepat mengenai persediaan barang serta mampu menampilkan laporan persediaan dan penjualan barang (Nasyifah, 2012).

Persamaan dari penelitian di atas dengan penelitian ini adalah tujuan dari pembuatan Sistem Informasi Persediaan dan Penjualan berbasis webitu sendiri yaitu untuk memberikan kemudahan bagi pengguna dalam melakukan kegiatan transaksi penjualan dan memberikan informasi persediaan barang dengan cepat dan akurat sehingga dapat meningkatkan kinerja dan dapat meningkat pendapatan. Dalam pembuatan sistem informasi persediaan dan penjualan obat batik berbasis web ini proses input transaksi penjualan dan informasi persediaan dapat dilakukan secara online oleh pengguna tanpa terbatas ruang dan waktu.

Sistem adalah kumpulan dari elemenelemen yang berinteraksi untuk mencapai suatu tujuan tertentu (Jogiyanto, 1999).Sistem juga didefinisikan sebagai sekumpulan hal atau kegiatan atau elemen atau sub sistem yang saling bekerjasama atau di hubungkan dengan cara-cara tertentu sehingga membentuk satu kesatuan untuk melakukan suatu fungsi guna mencapai suatu tujuan (Sutanta, 2003).Pengertian lainnya mengenaiSistem merupakan kumpulan elemen yang saling berkaitan yang bertanggung jawab memproses masukan (input) sehingga menghasilkan keluaran (output) (Kusrini, 2007).

Informasiadalah data yang diolah menjadi bentuk yang lebih berguna dan lebih berarti bagi yang menerimanya (Jogiyanto, 1999). Pengertian lainnya mengenai Informasi adalah hasil pemprosesan data yang diperoleh dari setiap elemen sistem tersebut menjadi bentuk yang mudah dipahami dan merupakan pengetahuan yang relevan yang dibutuhkan oleh orang untuk menambah pemahamannya terhadap fakta-fakta yang ada (Sutedjo, 2002).Informasijuga merupakan hasil olahan data, dimana data tersebut sudah diproses dan diinterprestasikan menjadi sesuatu yang bermakna untuk pengambilan keputusan (Kusrini,2007).

Dari definisi mengenai sistem dan informasi di atas, penulis mencoba membuat definisi sendiri untuk Sistem Informasi, yaitu sekumpulan data yang diolah menjadi sesuatu yang lebih bermanfaat bagi orang lain untuk mencapai tujuan tertentu.

Penjualan adalah suatu transaksi yang bertujuan untuk mendapatkan suatu keuntungan, dan merupakan suatu jantung dari suatu perusahaan (Himayati, 2008). Sedangkan Pembelian adalah suatu transaksi dimana perusahaan membutuhkan barang atau jasa, baik untuk dipakai maupun untuk persediaan 
yang akan dijual (Himayati, 2008). Pembelian juga bisa diartikan sebagai akun (purchasing)yang digunakan untuk mencatat semua pembelian barang dagang dalam suatu periode (Soemarso, 2009).

Persediaan adalah bahan atau barang yang disimpan yang akan digunakan untuk memenuhi tujuan tertentu, misalnya untuk digunakan dalam proses produksi atau perakitan, untuk dijual kembali, atau untuk suku cadang dari suatu peralatan atau mesin (Herjanto, 2006).

Batik adalah kain bergambar yang dibuat dengan teknik rintang warna. Bahan perintang yang digunakan adalah malam (lilin). Teknik rintang warna ini dilakukan dengan cara menorehkan malam panas menggunakan canting pada kain untuk membentuk gambar. Bagian yang ditutup malam ini pada saatproses pewarnaan tidak akan terkena warna, sehingga pada saat dilorod (menghilangkan malam) bagian ini tetap berwarna putih, dan membentuk motif (ragam hias) pada kain batik (Gratha, 2012).

Ada dua jenis zat warna batik, yaitu zat warna sintetis dan zat warna alami. Zat warna sintetisadalah zat warna yang dibuat bukan dari bahan tumbuh-tumbuhan melainkan pencampuran dari unsur-unsur kimia.Sedangkan zat warna alami adalah zat warna yang diperoleh dari hasil pengolahan tumbuh-tumbuhan (Kanaya, 2012).

Istilah internet berasal dari bahasa latin inter, yang berarti "antara". Internet (InterNetwork) adalah sekumpulan jaringan yang terhubung satu dengan yang lainnya, dimana jaringan menyediakan sambungan menuju global informasi. Pada umumnya untuk membangun sebuah jaringan internet membutuhkan peralatan jaringan seperti Repeater (penguat sinyal), Bridge (penghubung antar jaringan), Router (pengatur lalu lintas dalam jaringan) danGateway (Sutedjo dkk, 2007).
PHP dan MySQL

PHP (Hypertext Prepocessor)adalah satu bahasa pemrograman skrip yang dirancang untuk membangun aplikasi web. Ketika dipanggil dari web browser, program yang ditulis dengan $P H P$ akan di-parsing di dalam web server oleh interpreter PHP dan diterjemahkan kedalam dokumen $H T M L$, yang selanjutnya akan ditampilkan kembalidi webbrowser (Raharjo, 2012).Sedangkan MySQL merupakan sistem database yang banyak digunakan untuk pengembangan aplikasi web. MySQL termasuk dalam RDBMS (Relation Database Management System). $M y S Q L$ dapat berjalan baik di OS (Operating System)linux maupun windows(Raharjo, dkk 2012).

Basis data (database) adalah kumpulan terorganisasi dari data-data yang berhubungan sedemikian rupa sehingga mudah disimpan, dimanipulasi, serta dipanggil oleh pengguna (Nugroho, 2011).

\section{Metode Penelitian}

\subsection{Perancangan Sistem}

Jika ingin menghasilkan data yang dapat menjadi suatu informasi maka dibutuhkan suatu pengembangan sistem yang baru untuk diterapkan pada toko Warna Mulia. Dengan Sistem Informasi Penjualan dan Persediaan Obat Batik yang baru ini maka semua transaksi dapat dimasukan langsung pada database dan semua laporan juga dapat dilihat langsung pada database.

\section{a. Diagram Context}

Diagram Context untuk Sistem Informasi Penjualan dan Persediaan Obat Batik pada toko Warna Mulia dapat digambarkan seperti gambar 1 berikut : 


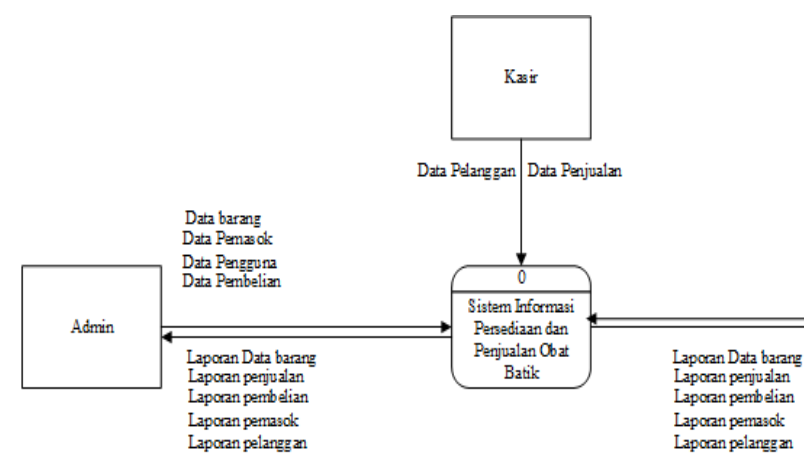

Gambar 1. Diagram Context

Diagram Context Sistem Informasi Persediaan Dan Penjualan Obat Batik pada toko Warna Mulia berbasis web seperti terlihat pada gambar 1 terlihat bahwa entitas Admin menginputkan data barang, data pemasok, data pengguna dan data pembelian serta akan menerima informasi laporan data barang, penjualan, pembelian, pemasok, dan pelanggan. Laporan-laporan tersebut juga akan dikirimkan ke entitas Pimpinan. Entitas Admin memperoleh data pelanggan dan data penjualan dari entitas Kasir melalui sistem.

b. DFD Level 0

Gambar 2 menunjukkan DFD level 0 yang merupakan turunan atau uraian dari Diagram Context.

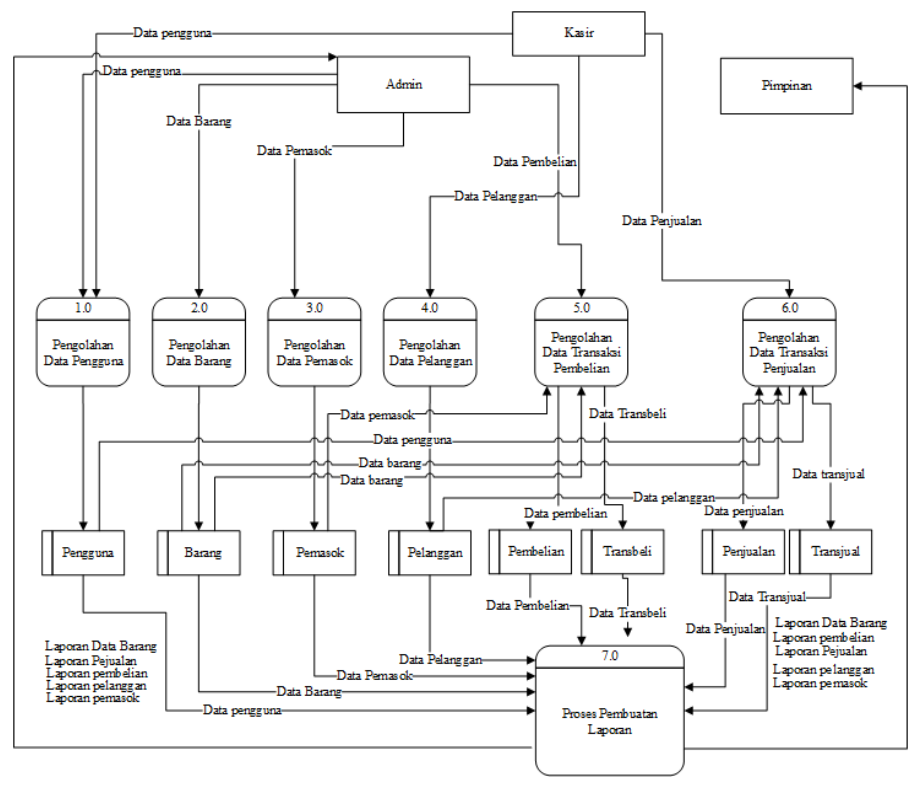

Gambar 2. DFD Level 0
Gambar 2. DFD Level 0 menunjukkan beberapa proses yaitu pemrosesan data pengguna, data barang, data pemasok, data pelanggan, data transaksi pembelian, data transaksi penjualan. Pada level-0, prosesproses di atas dikelompokkan menjadi 6 (enam).

\subsection{Rancangan Basis Data}

Basisdata digunakan untuk media penyimpanan data yang kemudian digunakan untuk menghasilkan informasi.

\section{a. Relasi tabel}



Gambar 3. Relasi tabel

Pada gambar 3 dijelaskan bahwa database yang dirancang terdiri dari dari 8 entitas yaitu pengguna, barang, pemasok, pelanggan, pembelian, transbeli, penjualan, transjual. Setiap entitas mempunyai attribut masing-masing dimana attribut dari masingmasing entitassaling berhubungan.

\section{Pembahasan}

\section{Hasil Sistem}

Setelah melalui tahapan perancangan sistem, maka didapatkan sebuah hasil sistem yang siap untuk digunakan. Adapun tampilan hasil sistem sebagai berikut : 
1. Tampilan Login



Gambar 4. Tampilan login

Ketika aplikasi website dibuka akan tampil halaman awal dimana pengguna akan ditampilkan halaman login seperti ditampilkan pada gambar 4 yang digunakan sebagai langkah awal pengunaan aplikasi. Sebelum pengguna dapat menggunakan aplikasi lebih lanjut pengguna harus login dimana pengguna harus memasukan hak akses, user name dan password dari pengguna tersebut.

2. Tampilan Menu Utama Admin

Ketika aplikasidibuka menggunakan hak akses admin akan tampil halaman utama. Tampilan halaman utama tersebut sebagai mana ditampilkan pada gambar 5 berikut :



Gambar 5. Tampilan menu utama admin
3. Tampilan Menu Utama Admin

Ketika aplikasilogin menggunakan hak akses admin akan tampil halaman utama. Tampilan halaman utama tersebut sebagai mana ditampilkan pada gambar 6 berikut :

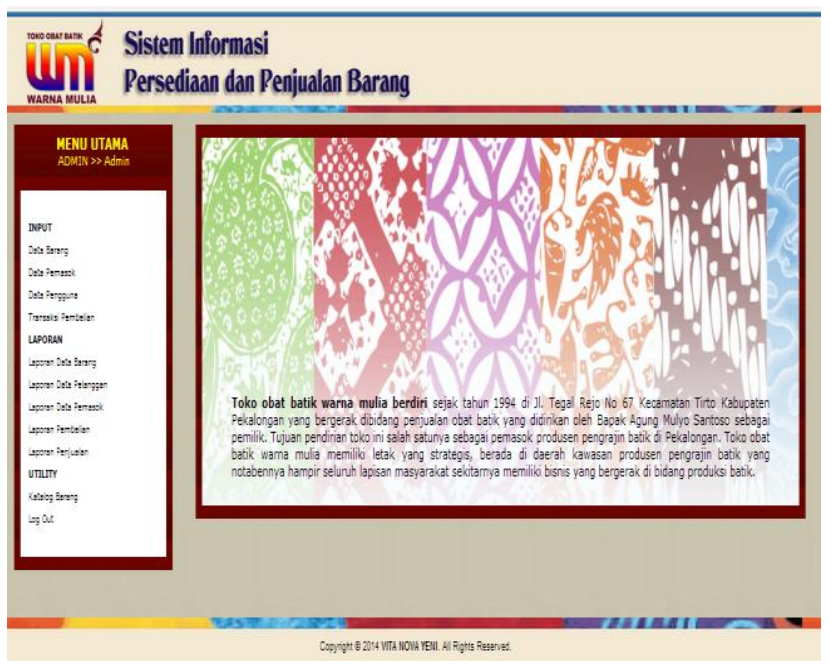

Gambar 6. Tampilan menu utama pimpinan

ada menu utama admin akan ditampilkan isi dari menu utama yang memiliki fungsi yang berbeda dari isi menu lain yang terdapat pada menu utama.

4. Tampilan Menu utama kasir

Ketika aplikasilogin menggunakan hak akses kasir akan tampil halaman utamasebagai mana ditampilkan pada gambar 7 berikut :.

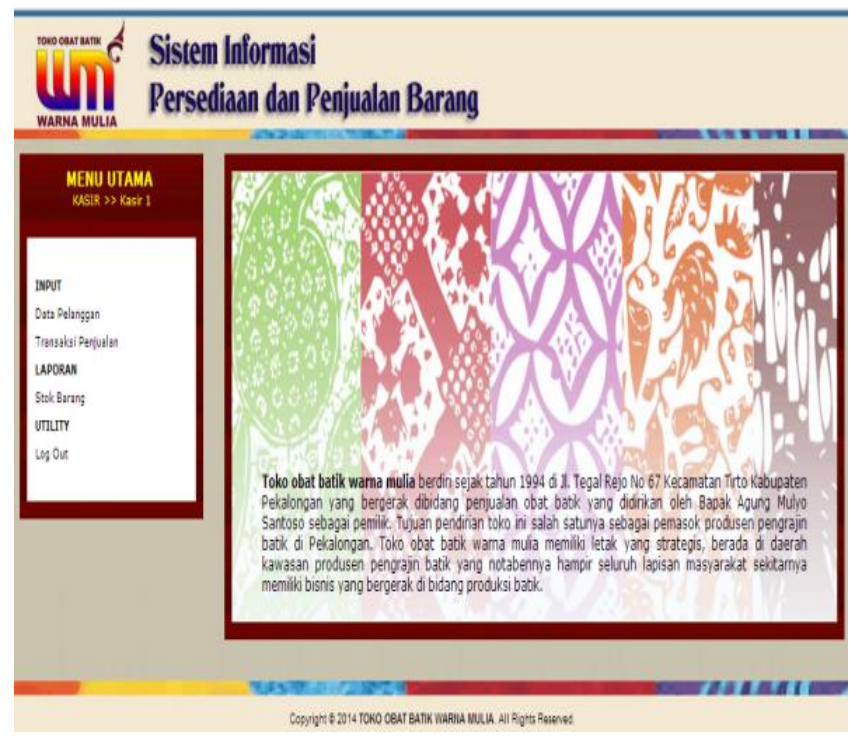

Gambar 7 Tampilan menu utama kasir 
Pada tampilan kasir berbeda dengan tampilan admin, pada tampilan kasir lebih sederhana dan hanya di gunakan untuk petugas kasir baik kasir di toko maupun kasir yang dilapangan (sales).

5. Tampilan data transaksi penjualan

Ketika menginputkan data transaksi penjualan yang dilakukan oleh kasir. Tampilannya sebagai sebagai mana ditampilkan pada gambar 8 berikut :

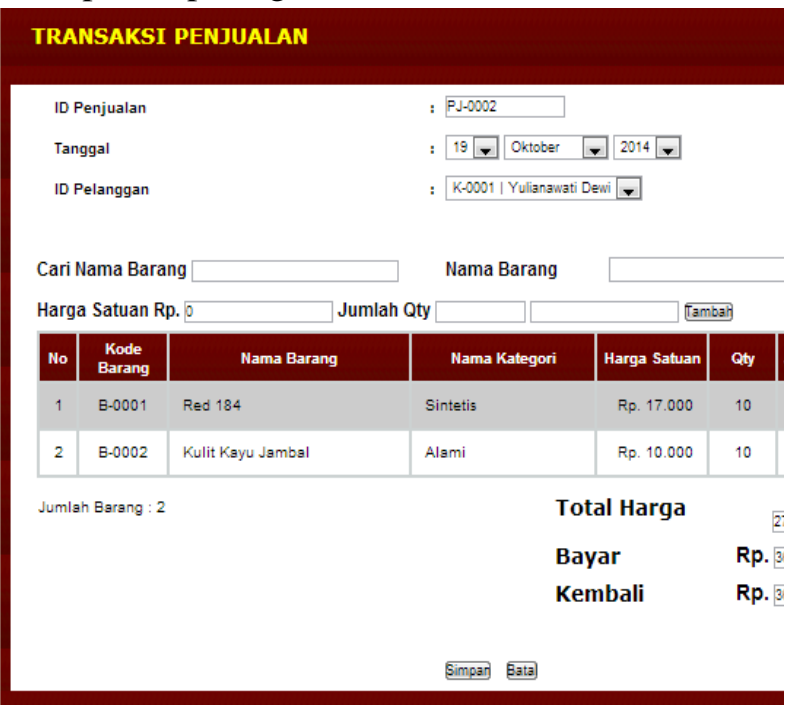

Gambar 8. Tampilan data transaksi penjualan

Pada menu halaman ini memiliki fungsi dimana pengguna dapat melakukan input data transaksi penjualan yang terjadi kemudian menyimpan kedalam database.

\section{Penutup}

\section{Kesimpulan}

Dari berbagai penjelasan yang diuraikan dalam laporan ini, maka dapat disimpulkan berbagai hal sebagai berikut:

1. Proses penjualan barang menggunakan aplikasi online yang secara otomatis terhubung langsung ke database toko.

2. Aplikasi ini berisi laporan proses transaksi penjualan, persediaan barang, pendapatan dan pengeluaran.

Saran

Ada beberapa saran untuk pengembangan sistem ke depan, diantaranya sebagai berikut :
1. Tampilan program aplikasi ini walaupun menggunakan javascript namun untuk tampilanya masih banyak kekurangan sehingga interface yang ditampilkan kurang menarik. Untuk kedepannya diharapkan tampilan atau interface program dapat dikembangkan menggunakan javascript yang lebih kompleks sehingga interface untuk aplikasi ini lebih menarik dan penggunaannya lebih mudah dan mempercepat proses pemasukkan data.

2. Untuk kelancaran dalam pengunaan aplikasi ini dianjurkan untuk mengunakan perangkat yang mendukung dan koneksivitas jaringan yang baik.

3. Untuk mendukung kedepannya nanti bisa ditambahkan fasilitas live chatting, sehingga komunikasi antara pegawai dan admin toko obat batik warna mulia dapat berjalan dengan baik demi kelancaran kinerja pegawai.

\section{Daftar Pustaka}

A Hall, James. 2007. Sistem Informasi Akuntansi edisi4. Jakarta : Salemba4.

Amsyah, Zulkifli. 2001. Manajemen sistem Informasi. Jakarta : Gramedia Pustaka Utama.

Elliot, McCabe. 2004. Batik : Fabled Cloth of Java. Singapore : Periplus.

Gratha, Benny. 2012. Panduan Mudah Belajar Membatik. Jakarta : Demedika Pustaka.

Herjanto, Eddy. 2006. Manajemen Operasi. Jakarta : Gramedia Widiarsana Indonesia.

Kadir, Abdul. 2003. Pengenalan Sistem Informasi. Yogyakarta : Penerbit Andi.

Kusrini. 2007. Tuntunan Praktis Membangun Sistem Informasi Akuntansi dengan Visual Basic dan Microsoft SQL Server. Yogyakarta : Penerbit Andi.

Madcoms. 2010. Kupas Tuntas Adobe Dreamweaver CS5 dengan 
Pemrograman PHP \& MySQL.

Yogyakarta : Penerbit Andi.

Mall, Rajib. 2009. Fundamentals of Software Engineering.

Marom, Chairul. 2002. Sistem Akuntansi Perusahaan Dagang. Jakarta : Grasindo.

Nugroho, Adi. 2011. Perancangan dan Implementasi Sistem Basis Data. Yogyakarta : Penerbit Andi.

Pradito, Didit. 2010. The Dancing Peacock and Motifs of Priangan Batik. Jakarta : Gramedia Pustak Utama.

Prasetyo, Kurniawan. 2007. Membuat Blog Menggunakan WordPress. Jakarta : Elex Media komputindo.

Raharjo, Budi. 2012. Modul Pemrograman WEB (HTML, PHP, MYSQL). Bandung : Modula.

Riyanto. 2010. Membuat Sendiri Sistem Informasi Penjualan dengan PHP dan $M y S Q L$. Yogyakarta : Gava Media.

Simamora, Henry. 2000. Basis Pengambilan Keputusan Bisnis 2. Jakarta : Salemba Empat.

Supardi, Yuniar. 2006. Sistem Penjualan Servicepart Kendaraan dengan Visual Basic 6.0 \& MySQL. Jakarta : Alex Media Komputindo.

Sutedjo, Budi. 2002. Perencanaan \& Pembangunan Sistem Informasi. Yogyakarta : Penerbit Andi.

Sutedjo, Budi. 2007. Pengantar Teknologi Informasi Internet, Konsep dan Aplikasi. Yogyakarta : Penerbit Andi.

Ulung, Gagas. 2011. Go Traditional. Jakarta :

Gramedia Pustaka Utama.

W Gulo. 2010. Metodologi Penelitian. Jakarta : Grasindo. 